\title{
Gentrification, transnational gentrification and touristification in Seville, Spain
}

Urban Studies

$1-16$

(c) Urban Studies Journal Limited 2019 Article reuse guidelines: sagepub.com/journals-permissions DOI: $10.1177 / 0042098019857585$ journals.sagepub.com/home/usj @SAGE

\section{Jaime Jover}

Centre for Geographical Studies, Universidade de Lisboa, Portugal

\section{Ibán Díaz-Parra}

Department of Human Geography, University of Seville, Spain

\begin{abstract}
Increased international tourism in large European cities has been a growing social and political issue over the last few years. As the number of urban tourists has rapidly grown, studies have often focused on its socio-spatial consequences, commonly referred to as touristification, and have linked this to gentrification. This connection makes sense within the framework of planetary gentrification theories because the social injustices it generates in cities have a global pattern. However, gentrification is a complex process that must be analytically differentiated from tourism strategies and their effects. Whereas gentrification means a lower income population replaced by one of a higher status, touristification consists of an increase in tourist activity that generally implies the loss of residents. Strategies to appropriate and marketise culture to sustain tourismled economies can also shape more attractive places for foreign wealthy newcomers, whose arrival has been theorised as transnational gentrification. Discussions on the relationship between gentrification, transnational gentrification and touristification are essential, especially regarding how they work in transforming an urban area's social fabric, for which Seville, Spain's fourth largest city with an economy specialised in cultural tourism, provides a starting point. The focus is set on the processes' timelines and similar patterns, which are tested on three consecutive scales of analysis: the city, the historic district and the Alameda neighbourhood. Through the examination of these transformations, the article concludes that transnational gentrification and touristification are new urban strategies and practices to revalorise real estate and appropriate urban surplus in unique urban areas.
\end{abstract}

\section{Keywords}

gentrification, housing, migration, Seville, Spain, touristification 


\section{摘要}

在过去的几年里，欧洲大城市国际旅游业的增长已经成为一个日益突出的社会和政治问

题。随着城市游客数量的快速增长, 研究往往集中于其社会空间后果（这通常被称为旅游 者化，touristification），并将其与绅士化联系起来。这种联系在全球绅士化理论的框架内 是有意义的, 因为它在城市中产生的社会不公正是一种全球规律。然而, 绅士化是一个复 杂的过程, 必须从分析上区别于旅游战略及其影响。绅士化意味着收入较低的人口被地位 较高的人口所取代，而旅游业则包括旅游活动的增加，这通常意味着居民的流失。为维持 旅游业主导的经济而采取适当的文化营销策略，也可以为外国富裕的新移民创造更有吸引 力的地方, 他们的到来被理论上称为跨国绅士化。关于绅士化、跨国绅士化和旅游者化之 间关系的讨论至关重要，特别是关于它们如何改变城市地区的社会结构，在这方面，经济 以文化旅游业为重点的西班牙第四大城市塞维利亚提供了一个研究的起点。我们的研究重 点放在过程的时间表和类似规律上, 这些规律在三个连续的分析尺度上进行测试: 城市、 历史地区和阿拉梅达 (Alameda) 街区。通过对这些转变的考察, 本文得出结论, 跨国绅 士化和旅游者化是在独特的城市地区稳定房地产和适当的城市剩余的新的城市战略和做 法。

\section{关键词}

绅士化、住房、移民、塞维利亚、西班牙、旅游者化

Received July 2018; accepted May 2019

\section{Introduction}

\section{Justification, objective and hypothesis}

Seville has broken its own record of annual tourists every year during the last decade, with the new record standing at 2.6 million visitors in 2017 (Martos, 2018). That number is likely to increase once again now that Lonely Planet has labelled Seville the number one city to visit in 2018. Tourism and its effects on the environment and culture, also referred to as touristification (Picard, 2003), have attracted scholarly attention in the Iberian Peninsula's major cities, including Barcelona, Madrid and Lisbon. However, less attention has been paid to other urban contexts such as Seville, Spain's fourth largest city and the capital and most populated urban conurbation in Andalusia. Andalusia is the most populous autonomous region in Spain, and one of the poorest in Western Europe: $35.7 \%$ of Andalusians are at risk of poverty and 55\% cannot afford a week's holiday in a year (Solís, 2016). The region's economy is heavily dependent on real estate and, above all, on tourism, which has emerged as the key sector in the aftermath of the economic crisis. Andalusia's economy relies on wealthy foreign visitors: tourists and lifestyle migrants, whose role in shifting urban processes calls for greater attention.

Gentrification is probably the most studied of those urban processes. It is defined as a social process that seeks to use a range of aggressive global scale strategies to reclaim urban centres for the middle and upper classes (Smith, 1996, 2002). Recent studies in gentrification have emphasised how this process is going planetary, although contingent on local context. Scholars are attentive to particularities of specific areas and institutions, but also to the similarities of conditions leading to gentrification across the world (Lees et al., 2016; Lopez-Morales et al., 2016). However, criticism towards gentrification research outside Western cities has pointed out its Anglo-Saxon cultural bias and the difficulties of gentrification theory in approaching and understanding radically different urban contexts (Delgadillo, 
2013; Maloutas, 2012). We argue that gentrification theory is a target of post-colonial criticism because of the academic tendency to give an excessive elasticity to definitions. This elasticity enabled classifying all types of neoliberal urban development or redevelopment under 'gentrification', thus losing the ability to describe nuanced urban processes (for further discussion, see Díaz-Parra, 2019). For this reason, a differentiation between gentrification, transnational gentrification and touristification is required.

This objective is especially important in the southern European context after the financial crisis, where scholars have linked gentrification to tourism and its socioeconomic implications (Cócola-Gant, 2016; Yrigoy, 2017), sometimes identifying touristification as the main reason for dispossession and displacement in central urban areas. We agree that the construction of vast tourist infrastructure and city-marketing campaigns in Seville - particularly in its historic district - have reinforced and fostered the most recent round of gentrification. However, we argue that while gentrification, transnational gentrification and touristification are interrelated processes, they could each have different timings in tourist-led urban economies and develop in particular ways that warrant attention. We begin from the hypothesis that urban transformation in Seville's historic district, and especially in the Alameda neighbourhood, are a result of an increasing number of (usually wealthy) lifestyle migrants and tourists. We will focus on the transnational aspects of urban change and analyse the role that foreign populations - of either migrants or tourists - play in it. We will also look at how this type of mobility intertwines with local factors. Our aim in this article is twofold - theoretical and practical. Understanding the differences in timing and modes of development of particular urban processes is important for urban theory, as it is for activists fighting against socio-spatial injustices to identify who is benefiting from each process and in what ways. At the same time, these distinctions can help policymakers form an adequate social policy to deal with rapid changes in Mediterranean cities.

\section{Methodology}

The emerging literature on urbanisation and gentrification as planetary processes (Lees et al., 2016) also has consequences for the methods used to approach them. A key consequence is that research must jump the scale of analysis from the neighbourhood upwards, adopting a relational, comparative inter-scale approach. For this reason, we substantiate our arguments through the analysis of empirical data at three consecutive and related scales in Seville: the city, the historic district and the Alameda neighbourhood. We start with an overview of the general context, addressing state-level statistics on direct foreign investment and international homeowners. We then analyse sociospatial changes in Seville at two scales: the city and the historic district. Finally, we focus on a specific case study in this area: the Alameda, the largest public space in the historic district. A degraded and almost entirely abandoned neighbourhood characterised by drug dealing, prostitution and homelessness in the 1990s, the Alameda has gone upscale in recent years.

We analyse demographic, housing and tourism data, and look at key bibliography, local press, urban planning and local policy documents during the last 25 years. We use a series of basic indicators across these three scales of analysis to approach and observe the different trends of each process. Gentrification is understood as a population of a lower socio-economic status being replaced by a higher status population, so we observe relative changes by neighbourhood in comparison with the city as a whole during the intercensal period. The analysed 
variable is the proportion of the population with a university degree, as this usually correlates highly with other socio-economic indicators. This information is readily available in the 1991, 2001 and 2011 censuses, this latter being partially a survey, so there may be some degree of data aggregation. Unfortunately, more recent data that would allow us to make comparisons is unavailable. In addition, availability of data on the variation in the proportion of poor housing conditions in individual areas compared with the city as a whole is limited to the 1991 and 2001 censuses. The numbers, fluctuation and whereabouts of foreigners from the 23 highest Human Development Index countries (for 2011, the same year as the last available census) are used as indicators of transnational gentrification. We also use other variables that help understand sociospatial transformations: real population growth; ageing and rejuvenation; and variation in housing (including second homes, vacancy rates and rental properties). This dataset is also taken from censuses. The economic character of tourism and its rapid growth, particularly in Seville, means that we have focused on a more recent timeline of analysis and have consulted other sources for touristification: the Andalusian Tourism Register and the DataHippo Project (www.datahippo.org) - for data on changes in tourism supply, focused on short-term holiday apartments and their distribution as well as relevant news reports.

\section{Recent debates: Gentrification, transnational gentrification and touristification in historic districts}

Gentrification is the replacement of population living in a certain area by others with higher status and income. The process is invariably accompanied by speculation, reinvestment and improvements to the built environment, as a result of the logic inherent in the way that the market works in the capitalist city (Clark, 2005). A period of disinvestment commonly preceded gentrification, as has been the case in European historic city centres during the 20th century. Disinvestment of historic centres was first a consequence of the expansion of peripheral neighbourhoods, according to the North American model (Gaja, 1992); urban centres were devalued, with the proliferation of abandoned buildings in a state of disrepair, and empty plots of land. This process spread across Spanish cities during the 1950s, 1960s and 1970s, and so did speculation once homeowners were aware of the future economic potential of those areas (Tomé, 2007; Troitiño, 2003). In addition, after the 1970s, planning progressively reconsidered the central areas of the consolidated city, prompting investment and revalorisation. In the Mediterranean context, especially in midsized cities such as Seville, this process was slower due to the economic situation and heritage regulations (Fernández Salinas, 1994). Therefore, gentrification only became significant there in the late 1980s and during the 1990s.

Revalorisation depended on urban renewal policies that have often been rooted in cultural policies. The economic exploitation of art and other expressions of heritage to symbolically revalorise central urban areas is a recurrent theme (Lees et al., 2016; Zukin, 1995), directly related to the exploitation of historic city centres for tourism uses. Towards the turn of the century and the new millennium, urban and cultural policies in southern Europe were aimed at tourism in order to (re)develop historic districts, where recovery and improvement encouraged more tourism. The success of cultural tourism expansion and consolidation strategies in historical urban spaces has been further driven by socio-spatial segregation processes, triggering the debate about tourism gentrification (Gotham, 2005). New urban cultures 
and lifestyles have influenced the practices of new residents and tourists, making tourism a new type of gentrification (Hiernaux and González, 2014). Urban changes of this type also affect new commercial uses, which include establishments almost exclusively aimed at tourists, especially those staying in short-term holiday rentals. As Cócola-Gant (2016) notes, the debate on the effects that this type of accommodation has on the city has gathered force after the emergence of platforms such as Airbnb and HomeAway.

However, tourism modifies our conceptual understanding of gentrification. While tourism gentrification may imply a process of population displacement by tourists, given their seasonal and transitory nature it does not involve the long-term replacement of those residents who are forced out, making it difficult to conceptualise the process as gentrification. Rather, it is more accurate to talk about touristification as a process that encompasses displacement as well as other material and symbolic consequences stemming from mass tourism on a given territory. In some urban spaces, mass tourism is incompatible with residential uses, as it deeply affects aspects such as housing prices, the nature of business composition, usage of public space, air quality, etc. Furthermore, the effects of these processes on historic city centres are contradictory, as they blur and may even destroy some of the cties' intangible heritage expressions and therefore their appeal. Touristification contributes to a loss of authenticity in these spaces by the sociospatial transformation of neighbourhoods in line with the needs of consumers with high purchasing power, but it cannot be strictly understood as gentrification because the tourists do not settle down permanently.

By contrast, lifestyle migrants do appropriate local space more permanently. Highly mobile foreigners from middle- and upper middle-class backgrounds - from exchange students to retired professionals - living in foreign cities like Seville have increased substantially in recent years, leading to new urban processes. This has come to be considered as transnational gentrification and has been addressed in developing countries, for example in Latin America - with all its particularities (Janoschka and Sequera, 2016) where a large number of gentrifiers in historic city centres come from the Global North (Hayes, 2018; Sigler and Wachsmuth, 2015). In First World countries, lifestyle migration has been studied in specific geopolitical contexts, such as Jerusalem (Zaban, 2017) and, more commonly, in coastal or rural locations, such as by Benson (2012) for the British in rural France. Transnational gentrification and touristification share some common aspects but it is nonetheless important to make an analytical distinction between them. The main difference is that long-term settlement by foreigners with higher purchasing power can appropriate the urban spaces of lower income regions and drive neighbourhood upscaling, or link with gentrification processes driven by privileged local groups. Lifestyle migrants, taking part in transnational gentrification, sometimes settle in tourist places such as historic districts, and they influence the commercial fabric in ways similar to tourists, but at the same time generate different ties with places, behaviours and social relationships than sporadic visitors.

\section{Context: Population and economic changes in Spain and Andalusia}

In the early 1980s, Spain transitioned to liberal democracy and shortly afterwards joined the European Union. Thus, there was an ongoing neoliberal restructuring of the economy that, among other things, resulted in a deep flexibilisation of the labour market and industrial reconversion (Naredo, 1996). Despite the European Union having 


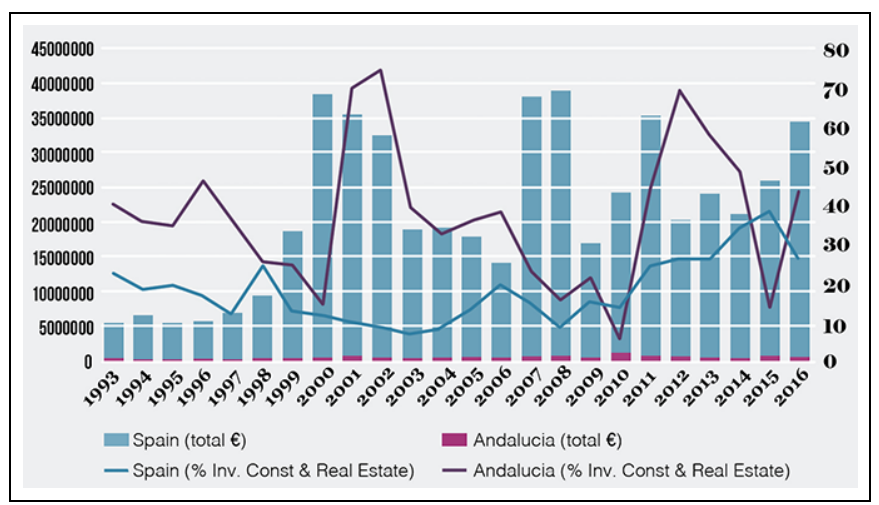

Figure I. Direct foreign investment in Spain and Andalusia (including percentage of the construction and real estate sector).

Source: Authors, from Datalnvex, Ministry of Economy, Government of Spain.

transited towards a service economy, countries such as France, Germany or the Netherlands still maintain a degree of diversity in their productive systems, whereas those on the southern periphery specialise in offering tourism and real estate products (Murray, 2015). According to the last WTO (2018) report, there were 1323 million tourists globally in 2017, and 82 million of them visited Spain, wherein there is an even stronger specialisation in certain regions. That is the case of Andalusia, the industrial base of which was weak at the beginning of the 1980 s, with an economy based on agriculture, construction and 'sun and sand' tourism. As the 20th century drew to a close, an economic model underpinned by construction and tourism consolidated, which became the seedbed for the real-estate bubble that made land and housing prices soar. The bubble burst after the 2007 crisis, when the sustained increase in housing stock, despite there being no real demand, meant that the new units being built could not be sold (Fernández-Tabales and Cruz, 2013). Figure 1 shows the timeline of absolute data for direct foreign investment in relation to the percentage that was invested in the construction and real estate sectors between 1993 and 2016. First, it shows how the flow of direct foreign investment into Andalusia was very small compared with Spain overall. Second, the percentage of direct foreign investment in Spain's construction and real estate has continued to grow after the crisis, especially from 2011, coinciding with further neoliberalisation of state legislation in terms of urban renewal and rehabilitation (Jover, 2017). Third, with few exceptions, the percentage of direct foreign investment in construction and real estate financing has been higher in Andalusia than in Spain as a whole in recent years, reaching a peak of almost $70 \%$ in 2012, which illustrates the region's greater specialisation in these sectors.

The growth of direct foreign investment has gone hand in hand with a greater presence of migrants. Numbers have soared in the past 20 years: in 1991 migrants made up a little over $1 \%$ of the Spanish population, whereas in 2011 they surpassed $11 \%$. In Andalusia, the figures are practically on a par with the State figure (data taken from Population and Housing Censuses, Spanish National Statistics Institute). A large part of the increase was due to greater numbers of Latin American and African migrants, especially between 1991 and 2001. However, as observed in 2011, the fastest growing nationalities are from European Union countries, 
particularly British, Germans and French, although the greatest increase was of Romanians. This rise has been reflected in the real estate market in recent years, with some special features that are worth highlighting. Unfortunately, only limited data is available on housing from the College of Spanish Property Registrars. Their 2006 statistical yearbook shows how almost $9 \%$ of house sales in Spain were to foreigners, with the British in first place, followed by Ecuadorians, Moroccans and Romanians. This is logical considering the population increases. In 2009, when house purchases collapsed nationwide, the foreign market share went down to $4.24 \%$, with buyers mainly from the United Kingdom, France, Germany and Russia. The market began to recover in 2012 and house purchasers also came from Sweden, Belgium and Norway. This amalgam of nationalities continues to this day, with the foreign market share growing to $13.25 \%$ in 2016 . The rising trend of foreign buyers is even greater in Andalusia, with the foreign market constituting $15.4 \%$ of transactions in 2016. During the postcrisis years, foreign buyers from central and northern Europe have helped to keep the Spanish property market afloat. These buyers, particularly in coastal areas such as Andalusia, are often lifestyle migrants, but also second-home owners (Murray, 2015).

\section{Analysis: Multi-scaled approach to changing socio-spatial dynamics in Seville}

\section{City scale}

Seville's economy started specialising in tourism as early as the beginning of the 20th century, which has affected the development of its urban structure. The main transformations are associated with the 1929 IberoAmerican Exhibition which shaped an early touristification process in the city (Díaz-
Parra, 2016). In general terms, there was a significant outflow of population from the historic district after the event and throughout most of the century, although in its southern part this loss - of mainly upper and middle classes - was replaced by intense tertiarisation and specialisation in tourism. In contrast, the northern part remained residential and unattractive to tourists, and suffered from depopulation, abandonment and downgrading, stigmatised for its workingclass population. The strategy of bolstering the economy through World Fairs was repeated in 1992 with the Seville International Exhibition, which again fostered an internal restructuring of the city. The aim was to improve the city's competitiveness through its consolidation as a tourist destination for international markets, which happened in the first decade of the new millennium as an average of 1.6 million tourists visited Seville yearly (data from Spanish Statistical Office), which is more than half of the city's population.

The gradual increase in tourism activity in Seville over the last 25 years and especially in the past decade has been very selective in spatial terms and concentrated in the entire historic district and adjacent neighbourhoods, such as Triana. These areas were subject to a classic gentrification process since the 1990s, with the working classes displaced and replaced by middle and upper middle classes (Díaz-Parra, 2010). The role of the municipal administration was at the heart of this process. The 1987 Master Plan, the main objective of which was to adapt the city to the Universal Exhibition requirements, implemented a slum clearance policy in the historic district's northern area, demolishing many buildings on the grounds of extreme urban and social degradation (Gerencia Urbanismo, 1987). Between 1995 and 1999, the Seville Urban Development Plan (Gerencia Urbanismo, 1994) co-funded over $€ 14$ million investment (mainly from 


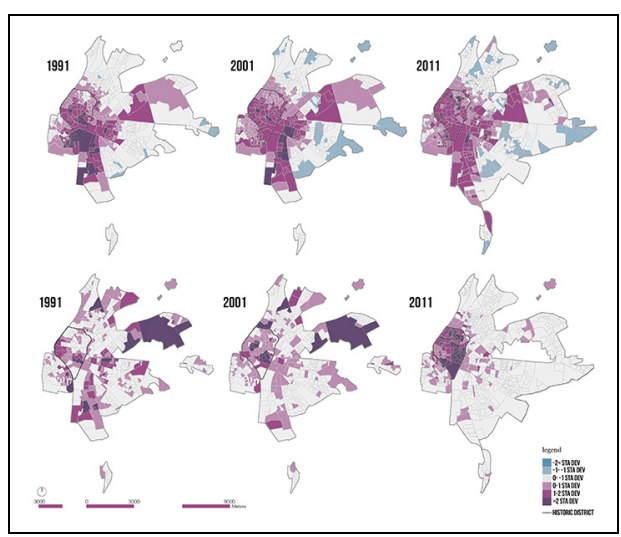

Figure 2. Distribution and clustering of the population holding a post-secondary degree (above) and foreign residents from the top-23 HDI countries (below) in Seville neighbourhoods (1991201I).

Source: Authors, based on Population and Housing Censuses.

the European Union) in social, infrastructure and equipment improvement programmes, including the restoration of emblematic buildings in the same area, which spurred further revalorisation of the built environment. In 2003, the Seville 2010 Strategic Plan aimed at intervening in degraded areas in the historic centre for the sake of tourism as the main economic activity. Simultaneously, the Plan adopted a similar discourse to social mixing policies in northern European countries (Lees, 2008; Uitermark, 2003), which inspired the 2006 Master Plan targeting the redevelopment of brownfield sites and empty lands. All these combined have acted as an engine to attract private investment and triggered strong speculative price increases. Because of these interventions, housing prices in the historic centre and Triana districts are the most expensive in Seville's housing market in terms of average price per square metre (Seville City Council, 2017).

The increasing difference in costs during this period between city centre housing and that of the outskirts was in line with the dynamic of refashioning the historic centre for the better-off and for tourist activity. Figure 2 looks at one indicator of gentrification: the percentage of the university graduate population in standard deviations around the average. Socio-spatial segregation in Seville is characterised by a coneshaped expanse of high earners that begins in the city centre and fans out towards the south-west. The main change observed over the years is the way that this privileged area has expanded towards the northern part of the historic district (including the Alameda area) which, even up to the 1990s, continued to be a run-down and undervalued area. Following the revalorisation of the city centre, the distribution of foreign residents in Seville from more highly developed countries has changed, shifting from a practically random distribution to a very clear cluster around this area.

The percentage represented by foreigners from wealthy countries living in Seville is small compared with the total population, as shown in Table 1. However, their numbers are concentrated in the historic district (Table 2) and in the Alameda district in particular (Table 3), and overlap with other indicators of socio-spatial concentration of privileged and upwardly mobile groups. Apart from the stagnation of Seville's population, there was also a noticeable ageing of the city's inhabitants between 1991 and 2011 (the over 65 category doubled) and an undeniable social advancement of the population according to indicators of university graduates and literacy rates. In addition, the number of empty dwellings in poor condition decreased and there was a slight decrease in the amount of rental housing and the number of empty dwellings and second homes.

However, Seville's consolidation as a tourist destination during the years under study has resulted in the greater relative importance of tourism activity for the urban 
Table I. Variation (199I-20II) in demographic and housing variables in Seville.

\begin{tabular}{llll}
\hline & 1991 & 2001 (var.) & 20II (var.) \\
\hline Population & 652,266 & 684,633 & 696,320 \\
\% Elderly & 8.57 & $15.18(+6.61)$ & $17.11(+1.93)$ \\
\% Illiterate & 21.32 & $22.70(+1.38)$ & $7.78(-14.92)$ \\
\% University graduates & 4.99 & $10.57(+5.58)$ & $22.24(+11.67)$ \\
\% Foreigners & 0.57 & $0.67(+0.11)$ & $5.14(+4.47)$ \\
\% Foreigners (23+HDI) & 0.29 & $0.17(-0.11)$ & $1.89(+1.72)$ \\
\% Buildings in good condition & 91.55 & $87.75(-3.80)$ & No data \\
\% Second homes & No data & 6.85 & $6.05(-0.80)$ \\
\% Empty housing & No data & 18.48 & $4.22(-14.26)$ \\
\% Rental housing & No data & 9.89 & $7.74(-2.15)$ \\
\hline
\end{tabular}

Source: Population and Housing Censuses.

Table 2. Variation (199|-20II) in demographic and housing variables in the historic district.

\begin{tabular}{llll}
\hline & 1991 & 2001 (var.) & 20II (var.) \\
\hline Population & $37,60 \mathrm{I}$ & 52,840 & 58,500 \\
\% Elderly & 17.49 & $20.37(+2.88)$ & $17.24(-3.13)$ \\
\% Illiterate & 25.89 & $15.90(-9.99)$ & $2.68(-13.22)$ \\
\% University graduates & 15.60 & $19.79(+4.19)$ & $43.02(+23.2)$ \\
\% Foreigners & 1.32 & $2.06(+0.74)$ & $8.63(+6.57)$ \\
\% Foreigners (23+HDI) & 0.69 & $0.83(+0.14)$ & $5.55(+4.72)$ \\
\% Buildings in good condition & 84.13 & $85.61(+1.48)$ & No data \\
\% Second homes & No data & 9.09 & $9.10(+0.01)$ \\
\% Empty housing & No data & 29.27 & $24.25(-5.02)$ \\
\% Rental housing & No data & 15.01 & $16.31(+1.30)$ \\
\hline
\end{tabular}

Source: Population and Housing Censuses.

Table 3. Variation (199|-20II) in demographic and housing variables in the Alameda area.

\begin{tabular}{llll}
\hline & 1991 & 2001 (var.) & 20II (var.) \\
\hline Population & 7561 & 7109 & 9460 \\
\% Elderly & 18.65 & $20.11(+1.46)$ & $12.94(-7.17)$ \\
\% Illiterate & 24.83 & $19.27(-5.56)$ & $3.33(-15.94)$ \\
\% University graduates & 6.39 & $17.58(+11.19)$ & $43.8(+26.2)$ \\
\% Foreigners & 0.84 & $2.14(+1.3)$ & $9.97(+7.83)$ \\
\% Foreigners (23+HDI) & 0.34 & $0.76(+0.42)$ & $6.4(+5.64)$ \\
\% Buildings in good condition & 76.96 & $87.45(+10.49)$ & No data \\
\% Second homes & No data & 10.71 & $7.73(-2.98)$ \\
\% Empty housing & No data & 30.55 & $35.06(+4.52)$ \\
\% Rental housing & No data & 18.28 & $14.03(-4.25)$ \\
\hline
\end{tabular}

Source: Population and Housing Censuses. 


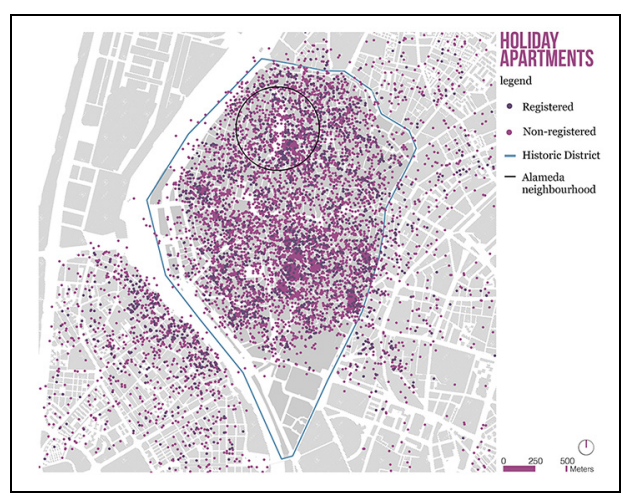

Figure 3. Distribution of holiday apartments (Airbnb and HomeAway) in Seville (February 20I8). Source: Authors, from Andalusian Tourism Register and datahippo.org.

economy, especially in the historic centre. There was a doubling of hotel establishments (from 105 to 238 between 1990 and 2016 according to the Andalusian Tourism Registry) to meet the increase in demand. Tourism supply has been growing on a par with demand in recent years, explaining the profit margin for housing units set aside for tourism use, which have leapt to over 7200 in just a few years. As seen in Figure 3, these are especially concentrated in the historic centre, including the Alameda neighbourhood, and only a third are legal according to the Andalusian Tourism Registry.

\section{Historic district scale}

As indicated above, the north-south polarisation of the historic district during the second half of the 20th century is key to understanding how the city operates, for example with respect to housing. Through the 1980 s and the early 1990 s, planning documents and local news highlighted the inadequate condition of the historic district in comparison with other urban areas. Due to the proximity of the 'decrepit and run-down' historic centre to the 1992 Exhibition grounds, public concern became alarmist, since it was 'the first landscape that tourists see when they arrive in Seville' $(A B C, 1989)$. Salas (1990), a well-known journalist and writer, considered the presence of an area of 'transvestites and prostitution' close to 'the main flagship of the city' to be unacceptable. That is why, following the 1987 Master Plan, construction activity was more intense in the northern half of the historic district and the criteria for preserving the built environment were more relaxed than in the southern half (Jover, 2017). Simultaneously, public housing policy has been weak there, which contributed to the rise in prices. Despite this, there has been a gradual return of residents to the historic district and the number of empty dwellings has fallen considerably (Table 2), in contrast to the great demographic decline in the period prior to the 1990s and to stagnation in Seville as a whole. Temporal changes in socio-economic characteristics should also be highlighted. For example, a quarter of the district's population was illiterate in 1991 compared with $2.68 \%$ in 2011 (city average: $7.78 \%$ ). This fall goes hand in hand with the increase in the population of university graduates: $43.02 \%$ of the district's inhabitants have university degrees and this variable has grown at twice the rate of the city as a whole, suggesting that a classic gentrification process has taken place. Part of the oldtime population has been pushed out, while newcomers are already of a different socioeconomic status, as reflected by their higher education levels.

The eviction of poor tenants in the previously downgraded areas within the historic district was generally the result of ruination and further demolition of old rental buildings, although there were also cases of tenants being harassed. The situation of elderly residents being dispossessed and potentially rendered homeless generated deep social concern and even hit the national press (Moreno, 2004). As a consequence, the 
City Council created an office to assess and protect vulnerable tenants, with their most remarkable measure being the expropriation and renovation of rental buildings to rehouse some of these tenants (Gerencia Urbanismo, 2003). This office also pushed for a more effective social housing policy, especially within the city centre (Diaz-Parra, 2010, 2014). However, these initiatives did not last and therefore had a low impact on restraining gentrification, as the census data show in Tables 2 and 3.

These data show a general increase in the number of migrants from more developed countries in the southern half of the city and in areas in the north of the historic district, such as the Alameda. It is especially worth noting that, while the population increase and the relative rise in the proportion of university graduates were especially strong during the 1991-2001 intercensal period, the increase in the number of foreigners from more developed countries did not really start to be felt until 2001-2011. More specifically, the most represented nationalities in 28 of the district's 53 sections in 2001 were from Latin America, Africa and Asia; however, this number had fallen to only nine of 52 sections in 2011 (from three countries: Argentina, China and Morocco). By contrast, increased numbers of French, German and Italian nationals stand out in 2011. This difference may indicate different timelines for gentrification: in the 1990s, locals were the ones leading the process, whereas in the following decade expatriates became more dominant.

Rising numbers of foreigners from highincome countries in neighbourhoods in the northern part of the historic district are linked to the urban renovation policy, which, in the last decade, has included interventions in the most important public spaces, such as the Alameda. This policy is part of a strategy aiming to consolidate the whole historic centre as a tourist destination and spread tourism beyond the traditional and congested tourist neighbourhoods in the south of the district, diversifying the offer through spatial redistribution. So, hotels and related businesses (restaurants and cafeterias aimed at foreign consumers, souvenir shops, etc.) have sprung up in the northern half. Notwithstanding, most of this infrastructure is concentrated in the southern half, around the UNESCO World Heritage sites, the Torre del Oro (Gold Tower) and María Luisa Park.

\section{Neighbourhood scale: The Alameda}

As previously mentioned, the Alameda area has undergone a radical transformation in the last 25 years. However, still in 2000, a renowned journalist lamented the 'survival of a cluster of social marginalization' there and asked for stronger measures to expel prostitutes and drug dealers (Camacho, 2000). The municipality agreed and developed the Alameda Renewal Plan (Gerencia Urbanismo, 2004), aiming at improving infrastructures and attracting private investment. Thereby the square itself was overhauled between 2004 and 2007, with most of the road traffic suppressed and subordinated to foot traffic and a new police station built to reinforce social control. Table 3 shows how in 1991 , only $76.9 \%$ of the buildings in the Alameda were in a good state of repair, compared with $90 \%$ in Seville as a whole (Table 1). It also reflects the existence of an amount of undervalued and deteriorated housing stock in comparison with the historic district (Table 2). The Alameda has seen greater improvement than the district as a whole, with growth in the number of buildings in a good state of repair that puts it on a par with the city as a whole. Table 3 also provides information about changes to types of residential buildings between 2001 and 2011. The amount of second homes went down in 2011, but the increase in empty housing - probably as a result of the 
mass evictions in a context of economic crisis - meant that there was virtually no variation in the degree of use of housing stock. More significant is the decreasing percentage of rental housing, from over $18 \%$ in 2001 to $14 \%$ in 2011. As the most vulnerable groups living in the sector were the ones occupying rental housing (Díaz-Parra, 2014), this change means that at least some of them were pushed out.

Regarding socio-demographic changes, the loss of population during the 1990s shows that the process of demographic decline was still ongoing, as opposed to the high population gains during the first 10 years of the 21 st century. Rejuvenation of the Alameda's population was even more intense than the general rejuvenation of the whole district. Moreover, data for education levels show an enormous increase in the number of people with higher education. Whereas the district as a whole improves, the Alameda undergoes an even more radical change. The increase in the number of people with university degrees cannot be explained by the structural social mobility of Seville's population as a whole (the rise in this figure is much lower for the city as shown in Table 1). Neither can it be explained by the influx of new middle-class inhabitants who keep the population at the same level as before (as the overall population of the Alameda dropped during the first intercensal period). Therefore, the most reasonable hypothesis is that higher status newcomers are replacing the pre-existing population.

Put together, these data indicate a major ongoing gentrification process in the Alameda area since the 1990s, involving the population's social advancement and the reinvestment in the built environment, but presenting a different timeline concerning the settlement of foreigners from highly developed countries. While the area experienced gentrification in the 1990s, the 2000s to 2010s already saw transnational gentrification there. As is the case of the historic centre (Table 2), the proportion of foreigners in the area is not really significant during the 1991-2001 intercensal period and their numbers only started growing between 2001 and 2011, when the foreign population almost doubles to $10 \%$, practically twice that of the average for the city. In 2011, the foreign population from more developed countries is $6.4 \%$ (with the overall figure for the historic centre standing at 5.5\%), which represents a considerable increase given that they represented only $0.76 \%$ of the total population in 2001.

The 'renaissance' of the Alameda area coincides with urban regeneration policies, which not only attract investment in building and new, young Spanish and foreign residents, but lately also tourism. The area has become fashionable, as the transformation of the commercial fabric and the proliferation of tourist accommodation suggest, which also indicates the beginning of a touristification process. Changes in the commercial fabric have resulted in an almost total loss of traditional retail and local shops, which have been replaced by modern bars and restaurants (with an increase of $230 \%$ since 1998) aimed at consumers with greater purchasing power (Díaz-Parra and Jover, 2018). Tourist accommodation has also grown noticeably. Three hotels have opened in the past 20 years, adding to the four that already existed. The seemingly low tourist density contrasts with the data on housing for tourist use, which has rapidly grown in the past few years. The data currently show 257 vacation homes in the Alameda (as of February 2018), whereas five years ago there were barely two dozen. However, this data is not disaggregated, in comparison with the registered holiday apartments that represent approximately a third of all those that currently exist. Seventy-nine legal housing units for tourism use exist in the Alameda neighbourhood, of which almost $15 \%$ belong to 
foreigners, with German and Italian owners predominating. This is a high figure bearing in mind that foreigners with registered tourist accommodation represent only $4.47 \%$ of the total in the city as a whole (data from the Andalusian Tourism Registry).

The success of Alameda as a tourist hotspot has raised new problems. As a result of the recent increase in night-time bars and pubs, residents have organised to protest about noise levels and the invasion of public spaces. The City Council responded by increasing controls on those establishments, but the measures were temporary and so the conflicts persist (Aguilar, 2016). Claims against landlords who do not renew rental contracts in order to turn their properties into short-term holiday rentals have gone hand in hand with this (Aguaza, 2017). The conflict has escalated in the last few years, with local associations, environmental groups and young educated residents organising together to criticise the tourism-led urban model and channel their claims against the situation in the area (El Correo, 2018).

\section{Conclusions}

This analysis shows that gentrification and recent tourist development in Seville's historic district are closely related, but also differentiable. Gentrification started in the district's northern neighbourhoods in the 1990s and has become more complex through the years as tourist activity has spread from the south. Traditionally residential areas such as Alameda have been added to the tourist circuits, with an increase in the number of holiday homes and a reduction in the supply of rental housing. Alameda has also experienced a renewed retail typology for higher income consumers, including foreign residents from higher income regions of Europe as well as tourists. Had it not been for urban regeneration fostered by the municipality, which in the late 20th century triggered a revalorisation of neighbourhoods in the historic district, tourism would most likely not have spread to Alameda. The results of such a policy are illustrated by changes to public spaces, building renovation and demographic statistics. In this sense, the data show that the decline of the area has been reversed by the entry of new populations, which we identify as gentrification.

A considerable minority of this new population in Seville settling in the Alameda and other areas in the city's historic district are foreigners from higher income countries. Growing numbers of lifestyle migrants settling in the district in recent years and the intensification of tourist activities justify greater attention to the transnational aspects of urban transformation and to the expressions of global inequalities in local space. The analysed data suggest that the relationship between gentrification, transnational gentrification and touristification is dialectical. On the one hand, these processes are working together on the creation and extraction of urban surplus value from a unique area. Increased numbers of local middle and upper middle classes in Alameda, mainly young professionals with university degrees, turned it into a safe and popular place, which has in turn attracted lifestyle migrants there. The tourist industry is profiting from the regeneration of the Alameda area and the population changes there, as the rapid increase in holiday rentals suggests. The concentrated pattern of lifestyle migrants in Seville's historic district seems to respond to a general search for a better quality of life, manifested in class-based lifestyle choices, modes of consumption and cultural attractions in the city. While this article based its methodology on population censuses and quantifiable data from other sources, indepth qualitative work - interviews for instance - is necessary for a deeper understanding of lifestyle migrants' motivations for 
settling in Seville's historic district. On the other hand, gentrification (local and transnational) and touristification could clash as they potentially push in different directions. Gentrification works to transform neighbourhoods for the socially privileged, while touristification aims to convert the same areas into exclusive tourist and commercefriendly places, meaning that few people - if any - live in them. A radical increase in tourism could bring about displacement, as well as conflicts over the use of public spaces or urban facilities and inconveniencies such as high noise or light pollution levels, making those spaces unattractive to reside in. Even if touristification in Alameda is at an early stage, there is already evidence for its differences regarding gentrification. Nevertheless, policies implemented in the past to contain the displacement and harassment of tenants, that is, to mitigate the effects of gentrification, could work against touristification too.

In sum, the Alameda became a cosmopolitan, young, middle- and upper middle-class area, in which urban marketing strategies and the growth of tourism have been key. This has occurred under circumstances of an economic crisis, from which Seville has successfully emerged due to its specialisation in tourism. The multiscale methodology used to analyse socio-spatial transformation illustrates the way that tourism has become a fundamental sector in the Spanish and Andalusian contexts and even more so in the case of Seville's urban economy. Simultaneously, it also shows how transnational gentrification and touristification are complementary processes to gentrification, sharing some of its patterns and diverging in others. Tourism has significant links with the real estate market, and therefore Seville's specialisation in tourism sees increased investment in both sectors. As this article shows, tourist and lifestyle migrants may be part of the same phenomenon, but their effects on the urban space differ from each other. Both transnational gentrification and touristification in Seville - driven mainly by European lifestyle migrants and tourists - call for a closer examination of the growing inequality between states, regions and cities within the European Union and the existence of dependency relationships in this common project.

\section{Acknowledgements}

The authors would like to thank Matthew Hayes and Hila Zaban for their helpful insights and suggestions as well as three anonymous referees for their comments on earlier drafts of this text. The usual disclaimers apply.

\section{Declaration of conflicting interests}

The author(s) declared no potential conflicts of interest with respect to the research, authorship, and/or publication of this article.

\section{Funding}

The author(s) received no financial support for the research, authorship, and/or publication of this article.

\section{ORCID iD}

Jaime Jover (iD) https://orcid.org/0000-0002-17961655

\section{References}

$A B C$ (1989) Prostitución en la carretera. 19 May, p. 22.

Aguaza P (2017) Barrios sin vecinos por la turistización. El Salto, 27 September. Available at: https://www.elsaltodiario.com/turismo/turistifi cacion-barrios-sin-vecinos (accessed 8 October 2018).

Aguilar C (2016) Es surrealista que la Alameda no se declare zona acústicamente saturada. $A B C, 28$ March. Available at: https://sevilla. abc.es/sevilla/sevi-surrealista-alameda-no-decla re-zona-acusticamente-saturada-201603272201_ noticia.html (accessed 8 October 2018).

Benson M (2012) How culturally significant imaginings are translated into lifestyle migration. 
Journal of Ethnic and Migration Studies 38(10): 1681-1696.

Camacho I (2000) Alameda de Hércules: Cirugía y no maquillaje. $A B C, 23$ December, p. 40.

Clark E (2005) The order and simplicity of gentrification - a political challenge. In: Atkinson $\mathrm{R}$ and Bridge G (eds) Gentrification in a Global Context: The New Urban Colonialism. Oxford: Routledge, pp. 261-269.

Cócola-Gant A (2016) Holiday rentals: The new gentrification battlefront. Sociological Research Online 21(3): 1-9.

Delgadillo V (2013) América Latina urbana: La construcción de un pensamiento teórico propio. Entrevista con Emilio Pradilla Cobos. Andamios 10: 185-202.

Díaz-Parra I (2010) Sevilla, cuestión de clase. Una geografía social de la ciudad. Seville: Atrapasueños.

Díaz-Parra I (2014) ¿Gentrificación o barbarie? Disciplinamiento y transformación social del barrio de la Alameda de Sevilla. Seville: Atrapasueños.

Díaz-Parra I (2016) Sevilla 1929-1992. La producción de una mercancía. In: Grupo de Estudios Antropológicos La Corrala (ed.) Cartografía de la ciudad capitalista. Madrid: Traficantes de Sueños, pp. 195-201.

Díaz-Parra I (2019) La gentrificación, entre la ecología urbana y la teoría de la renta. In: Bournazou E (ed.) Gentrificación. Miradas desde la academia y la ciudadanía. México DF: UNAM, pp. 31-52.

Díaz-Parra I and Jover J (2018) Enclaves urbanos de éxito. Transformación urbanística, gentrificación y turismo en la Alameda de Hércules de Sevilla. In: Gasca-Zamora J (ed.) Capital inmobiliario. Producción y transgresión del espacio social en la ciudad neoliberal. Mexico DF: Universidad Nacional Autónoma de México, pp. 337-357.

El Correo (2018) Nace un colectivo contra la turistización de Sevilla. 29 April. Available at: http://elcorreoweb.es/sevilla/nace-un-colectivocontra-la-turistizacion-de-sevilla-CX4110646 (accessed 8 October 2018).

Fernández Salinas V (1994) Los centros históricos en la evolución de la ciudad Europea desde los años setenta. Ería 94: 121-131.
Fernández-Tabales A and Cruz E (2013) Análisis territorial del crecimiento y la crisis del sector de la construcción en España y la Comunidad Autónoma de Andalusia. EURE 39(116): 5-37.

Gaja F (1992) Teorías para la intervención urbanistica en la ciudad preindustrial. Valencia: Universitat Politècnica de València.

Gerencia de Urbanismo (1987) Plan General de Ordenación Urbana. Seville: Ayuntamiento de Sevilla.

Gerencia de Urbanismo (1994) Proyecto Urban: San Luis-Alameda. Seville: Ayuntamiento de Sevilla.

Gerencia de Urbanismo (2003) Plan Municipal de Vivienda 2003-2007. Seville: Ayuntamiento de Sevilla.

Gerencia de Urbanismo (2004) Proyecto de regeneración y adecuación de la Alameda de Hércules. Seville: Ayuntamiento de Sevilla.

Gotham KF (2005) Tourism gentrification: The case of New Orleans' Vieux Carre. Urban Studies 42(7): 1099-1121.

Hayes M (2018) Gringolandia: Lifestyle Migration Under Late Capitalism. Minneapolis, MN: University of Minnesota Press.

Hiernaux D and González I (2014) Turismo y gentrificación: Pistas teóricas sobre una articulación. Revista de Geografía Norte Grande 58: 55-70.

Janoschka M and Sequera J (2016) Gentrification in Latin America: Addressing the politics and geographies of displacement. Urban Geography 37(8): 1175-1194.

Jover J (2017) Volviendo al Centro Histórico. La recuperación diferencial del patrimonio y su supeditación a las dinámicas urbanísticas: el caso de Sevilla. $\mathrm{PhD}$ dissertation, University of Seville. Available at: https://www.academia.edu/33717996/Volvien do_al_centro_hist $\% \mathrm{C} 3 \%$ B3rico (accessed 23 December 2017).

Lees L (2008) Gentrification and social mixing: Towards an inclusive urban renaissance? Urban Studies 45(12): 2449-2470.

Lees L, Shin HB and López-Morales E (2016) Planetary Gentrification. Cambridge: Polity Press. 
López-Morales E, Shin HB and Lees L (2016) Latin American gentrification. Urban Geography 37(8): 1091-1108.

Maloutas T (2012) Contextual diversity in gentrification research. Critical Sociology 38(1): 33-48.

Martos E (2018) Todo el año es ya temporada alta en Sevilla. $A B C, 23$ January. Available at: http://sevilla.abc.es/sevilla/sevi-todo-temporadaalta-sevilla-201801232335_noticia.html (accessed 24 January 2018).

Moreno E (2004) Desalojo en Sevilla. El País, 29 March. Available at: https://elpais.com/diario/ 2004/03/29/andalucia/ 1080512526_850215.html (accessed 12 October 2018).

Murray I (2015) Capitalismo y Turismo en España. Barcelona: Alba Sud.

Naredo JM (1996) La burbuja inmobiliariofinanciera en la coyuntura económica reciente (1985-1995). Madrid: Siglo XXI.

Picard M (2003) Touristification and balinization in a time of reformasi. Indonesia and the Malay World 31(89): 108-118.

Salas N (1990) Realidades 92. ABC, 23 April, p. 76.

Seville City Council (2017) Avance del Plan Municipal de la Vivienda 2018-2023. Seville: EMVISESA.

Sigler T and Wachsmuth D (2015) Transnational gentrification: Globalisation and neighbourhood change in Panama's Casco Antiguo. Urban Studies 53(4): 705-722.

Smith N (1996) The New Urban Frontier: Gentrification and the Revanchist City. London: Routledge.
Smith N (2002) New globalism, new urbanism: Gentrification as global urban strategy. Antipode 34(3): 427-450.

Solís R (2016) Así vive el 35,7\% de andaluces que duermen en el umbral de la pobreza. El Diario, 11 July. Available at: http://www.eldiario. es/andalucia/vive-andaluces-duermen-umbralpobreza_0_529147254.html (accessed 9 December 2017).

Tomé S (2007) Los centros históricos de las ciudades españolas. Ería 72: 75-88.

Troitiño MA (2003) La protección, recuperación y revitalización funcional de los centros históricos. In: Capel H (ed.) Ciudades, arquitectura y espacio urbano. Almería: Caja Rural Almería, pp. 131-160.

Uitermark J (2003) 'Social mixing' and the management of disadvantaged neighbourhoods: The Dutch policy of urban restructuring revisited. Urban Studies 40(3): 531-549.

WTO (World Tourism Organization) (2018) Annual report 2017. Available at: https://www. e-unwto.org/doi/pdf/10.18111/9789284419807 (accessed 4 October 2018).

Yrigoy I (2017) Airbnb en Menorca: ¿Una nueva gentrification turística? Localización de la vivienda turística, agentes e impactos sobre el alquiler residencial. Scripta Nova XXI(580): $1-31$.

Zaban H (2017) City of go(1)d: Spatial and cultural effects of high-status Jewish immigration from Western countries on the Baka neighbourhood of Jerusalem. Urban Studies 54(7): 1539-1558.

Zukin S (1995) The Culture of Cities. Oxford: Blackwell. 